\title{
Responses Of Interest Rates In Mexico To U.S. Monetary Policy
}

Yu Hsing, (Email: yhsing@selu.edu), Southeastern Louisiana University

\begin{abstract}
This paper examines potential responses of interest rates in Mexico to the U.S. monetary policy. The regression is cointegrated in that the dependent and independent variables have a long-run stable relationship. The GARCH or ARCH model is applied to estimate regression parameters. The results show that the T-bill rate, the cost of funds rate, and the time-deposit rate in Mexico are significantly affected by the change in the U.S. federal funds rate. In addition, these interest rates are negatively associated with real M2 and real tax revenues and positively affected by the real exchange rate, real government spending, and the expected inflation rate.
\end{abstract}

\section{Introduction}

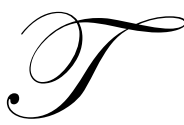

he Mexican economy has gone through spectacular changes during the last two decades. The passage of the NAFTA has benefited its export, agricultural, manufacturing and other related sectors as evidenced by the increase in employment from 32.83 million in 1993 to 39.07 million in 1999 and the decline in the unemployment rate from $2.40 \%$ to $1.72 \%$ during the same period. Thanks to the central bank's relatively independent role in recent years, the inflation rate dropped from 38.93\% in 1988.Q1 to 0.68\% in 2001.Q3. After the peso crisis beginning in late 1994, peso's value has been relatively stable during and after the Asian financial crisis and has risen from 10.02 pesos per U.S. dollar in 1998.Q4 to 9.22 in 2001.Q3 while most of other foreign currencies depreciated in value. While the U.S. experienced the longest economic expansion, Mexico faced with economic ups and downs due to financial, fiscal, peso, political and other crises. The financial market has become relatively stable as evidenced by the movements of the T-bill rate, which reached a high of $134.47 \%$ in 1988.Q1 and declined to 8.74\% in 2001.Q3.

In order to stimulate the sluggish economy, since January 2001 the Federal Reserve Bank has dropped the federal funds rate eleven times from $6.75 \%$ to $1.75 \%$. Facing with economic downturns, many foreign countries have followed suit to reduce key interest rates. The time-deposit rate in Mexico declined from a high of $106.45 \%$ in 1988.Q1 to a low of 3.84\% in 2001.Q3. A lower deposit rate is expected to reduce the incentive to save and increase current consumption. On the other hand, because Mexico has a relatively high saving rate (21.5\% in 2000), the loss of interest income for savers is expected to reduce consumption spending. The cost of funds rate dropped from $125.19 \%$ in 1988.Q1 to 7.74\% in 2001.Q3. Due to a lower cost of borrowing by households and firms, it is expected to increase aggregate demand and real output.

The purpose of this paper is to determine whether interest rates in Mexico respond to U.S. monetary policy and to estimate regression parameters for policy reference. This paper differs from most of previous studies in several aspects. First, a general equilibrium of the IS-LM model is applied so that relevant explanatory variables are considered. Second, the sample runs to 2001.Q3 so that potential impacts of U.S. monetary policy to reduce the federal funds rate on Mexican interest rates may be captured. Third, an advanced econometric methodology is applied so that regression parameters would be unbiased and efficient.

Readers with comments or questions are encouraged to contact the author via email. 


\section{Literature Survey}

There are several recent articles that examined the determinants of the interest rate and related subjects in the U.S. and other countries. Hoelscher (1983) examined the impact of federal budget deficits and debt on interest rates in the U.S. Based on different definitions of deficits and sample periods. He concluded that nominal interest rates are not significantly affected by an increase in federal borrowing. Barth, Iden and Russek $(1984,1985)$ indicated that U.S. interest rates are quite sensitive to the selection of the type of interest rates and independent variables, how budget deficit or government debt is measured, and the sample periods. They found that rising deficits and debt levels raise interest rates, reduce investment and consumption expenditures, cause money demand to decline, and shift aggregate demand to the left.

Al-Saji (1991) studied real interest rates for Italy. Expected inflation rates, money supply, deficits, and government spending were considered. He reported that real interest rates are positively associated with deficits and government spending. However, real rates were not affected by expected inflation rates and money supply.

Bremnes, Gjerde and Soettem (2001) employed the variance decomposition and impulse response functions to find the potential links of interest rates among the U.S., Norway and Germany. They found that interest rates in Germany and Norway are significantly affected by the interest rate in the U.S. and that the interest rate in Norway is also influenced by that in Germany. Laopodis (2001) investigated whether German interest rate is dominant within the EMS because of its economic strengths. He found that the German dominance hypothesis cannot be supported mainly because interest rates within the EMS are also influenced by other major nations.

Junttila (2001) found that there is long-run stable relationship between the nominal interest rate and the inflation rate for Finland. He also indicated that other factors of major trading nations should also be considered. However, Coppock and Poitras (2000) found that the full Fisher effect of a one-for-one relationship between the nominal interest rate and the expected inflation rate is not supported empirically. After controlling for country sovereign risk, they cited the premium on financial assets as the additional major factor.

McDonald and Nagayasu (2000) studied the relationship between the real interest rate and the real exchange rate for 14 nations. They found that there is a significant long-run relationship between these two variables.

Some of the studies testing for the Fisher effect or the relationship between the interest rate and the exchange rate may omit relevant explanatory variables. Several studies did not test whether error variance may follow the generalized autoregressive conditional heteroskedasticity $(\mathrm{GARCH})$ process. Although pooling countries increases the sample size and may have more policy implications, a case study may also shed new insight into the issues.

\section{The Model}

The nominal interest rate can be determined by a general equilibrium in the IS-LM model (Barth, Iden and Russek, 1984-1985, 1985; Gali, 1992; McCallum and Nelson, 1999). Suppose that consumption spending (C) is a function of disposable income and the real interest rate, that investment spending (I) is affected by the real interest rate, that net exports $(\mathrm{NX})$ are influenced by the real exchange rate, and that real money demand $(\mathrm{M} / \mathrm{P})$ is determined by real GDP and the nominal interest rate. The equilibrium equations in the goods and money markets can be expressed as

$$
\begin{aligned}
& \mathrm{Y}=\mathrm{C}(\mathrm{Y}-\mathrm{TX}, \mathrm{RR})+\mathrm{I}(\mathrm{RR})+\mathrm{GV}+\mathrm{NX}(\mathrm{EX}) \\
& \mathrm{M} / \mathrm{P}=\mathrm{L}(\mathrm{Y}, \mathrm{NR})
\end{aligned}
$$


where

$\mathrm{Y}=$ real GDP;

TX = government taxes;

$\mathrm{RR}=$ the real interest rate;

$\mathrm{RR}=\mathrm{NR}-\square^{\mathrm{e}}$;

$\mathrm{NR}=$ the nominal interest rate;

$\square^{\mathrm{e}}=$ the expected inflation rate.

$\mathrm{GV}=$ government spending;

$\mathrm{EX}=$ the real exchange rate;

$\mathrm{M}=$ nominal quantity of money; and

$\mathrm{P}=$ the general price level.

Combining equations (1) and (2), solving for the equilibrium nominal interest rate ( $\left.\mathrm{NR}^{*}\right)$, and adding the U.S. federal funds rate, we have

$\mathrm{NR}^{*}=\mathrm{f}\left(\mathrm{M} / \mathrm{P}, \mathrm{TX}, \mathrm{GV}, \mathrm{EX}, \square^{\mathrm{e}}, \mathrm{FFR}\right)$

The sign of M/P should be negative because an increase in M/P will shift the LM curve to the right and reduce the interest rate. The sign of TX is expected to be negative as a rise in TX will shift the IS curve to the left and cause the interest rate to decline. An increase in GV is expected to shift the IS curve to the right and raise the interest rate. An increase in the real exchange rate (EX) means a depreciation of the Mexican peso and is expected to increase net exports, which will in turn shift the IS to the right and raise the interest rate.

For savers, an increase in the real interest rate is expected to have a negative substitution effect and a positive income effect. For borrowers, an increase in the interest rate is likely to result in a negative substitution effect and a negative income effect. Because the impact of a change in the real interest rate on consumption spending is ambiguous, an increase in the expected inflation rate may or may not raise the interest rate.

The impact of the federal funds rate (FFR) on Mexico's interest rates is expected to be positive. The influence of U.S. monetary policy is worldwide and is likely to be followed by the central bank in Mexico. There are benefits for the Bank of Mexico to follow the Fed's decision to lower interest rates. The costs for the Mexican government, firms or households to borrow money in the short run are expected to be lower. It will reduce government debt burden and stimulate the economy.

\section{Empirical Results}

The data came from the International Financial Statistics published by the International Monetary Fund. The sample ranges from 1983.Q1 to 2001.Q3. Some of the data earlier or later than this period are not available. The cost of funds is employed to represent the lending rate, which does not have the complete data. The real exchange rate is defined as the ratio of Mexican pesos per U.S. dollar divided by the ratio of the price in the U.S. to the price in Mexico. Therefore, an increase in real exchange rates means depreciation for Mexican pesos. M2 money is used to measure the quantity of money. CPI is used to derive Real M2. The expected inflation rate is constructed from the average inflation rate of past four quarters. The logarithmic form is employed in order to calculate the elasticity or sensitivity of the interest rate to the change in one of the explanatory variables. Three interest rates are selected in empirical work. They are the T-Bill rate, the time-deposit rate, and the cost of funds rate.

The unit root is tested first. Based on the ADF test, one finds that each variable is I(1) in the level form but is $\mathrm{I}(0)$ in the difference form. According to the Johansen cointegration test allowing for linear deterministic trend in data with intercept and no trend or with intercept and trend in equation (4), the null hypothesis of one cointegrating relationship between real output and the right-hand side variables cannot be rejected at the $1 \%$ or 5\%level, because the trace statistics are greater than the critical values. Thus, the interest rate and the explanatory variables have a 
long-run stable relationship.

The $\operatorname{ARCH}(\mathrm{p}, \mathrm{q})$ model is applied to determine whether error variance may violate classical properties and whether better parameter estimates and statistical outcomes may be obtained. Different GARCH or ARCH processes are chosen for three different interest rates based on the significant coefficients for the past squared residual and/or past residual variance. The results are presented in Table 1.

All the coefficients are significant at the $1 \%$ or $5 \%$ level. The signs are as expected. Because the log scale is used, the estimated coefficient can be interpreted as the elasticity. The elasticity estimates range from 0.106 for CFR to 0.225 for TBR and 0.320 for TDR. It suggests that if the FFR rises by 1\%, CFR, TBR, and TDR will increase by $0.106 \%, 0.225 \%$, and $0.320 \%$, respectively. An interesting finding is that the coefficient for EX is relatively large. For example, if the real exchange rate depreciates by $1 \%$, TBR will rise by $2.182 \%$ due to the increase in net exports and the shift of IS curve to the right. Another interesting finding is that the elasticity of the interest rate with respect to real government spending is less than that of real government taxes. It suggests that the interest rate is more sensitive to the change in government taxes than government spending. The magnitude of the coefficients for the expected inflation rate suggests that nominal interest rate responds to the expected inflation rate significantly and that the elasticity is relatively small ranging from 0.124 to 0.388 .

If the OLS method is used to estimate regression parameters, one will obtain different outcomes and may draw misleading conclusions. In (A), the coefficients for $\square^{\mathrm{e}}$ and FFR will be insignificant at the $5 \%$ level. In (B), the coefficients for M/P, GV, and FFR are insignificant and the sign of FFR is negative. In (C), the coefficients of GV and FFR will be insignificant. Therefore, the choice of a more advanced econometric methodology would yield better statistical outcomes. Due to limited space, the results are not presented and will be available upon request.

\section{Summary and Conclusions}

In this study, the impact of U.S. monetary policy on the Mexican interest rates has been examined. The ISLM model is applied. The GARCH process is employed in empirical work. All three selected interest rates are affected by the federal funds rate with different degrees of sensitivity. They are less elastic because the magnitude is less than one. Interest rates in Mexico are also influenced by other relevant variables. Peso depreciation, higher inflation expectation, or more government spending will raise interest rates in Mexico. More real M2 or more taxes will lower interest rates.

There are policy implications. Because of relatively high saving rate in Mexico, lower interest rates in Mexico are likely to cause less interest income, which may reduce household spending. The relatively high value of the elasticity of the real exchange rate suggests that the Mexican government should be cautious in conducting its exchange rate policy. The finding that the coefficient of GV is less than that of TX in absolute value is interesting and may deserve more analysis. The conventional wisdom is that the positive multiplier effect of the government spending on real GDP is greater than the negative multiplier effect of government tax on real GDP. It may not apply to the interest rate.

There may be areas for potential future research. If the data is available, wealth may be considered in the consumption function. As the stock market becomes more volatile, it may affect financial wealth and consumption spending. The impact of budget deficits on the interest rate may be estimated with different measures. The expected inflation rate may be constructed with some other methodologies. 
Table 1 Estimated Regressions

\begin{tabular}{|l|c|c|c|}
\hline & $(\mathrm{A})$ & $(\mathrm{B})$ & $(\mathrm{C})$ \\
\hline & TBR & TDR & CFR \\
\hline M/P & $-0.205(-3.843)$ & $-0.309(-3.433)$ & $-0.261(-6.267)$ \\
\hline TX & $-0.526(-3.752)$ & $-1.022(-4.576)$ & $-0.602(-3.111)$ \\
\hline GV & $0.340(3.623)$ & $0.236(2.284)$ & $0.225(2.580)$ \\
\hline$\square^{\mathrm{e}}$ & $2.182(12.374)$ & $1.896(6.616)$ & $1.915(11.944)$ \\
\hline FFR & $0.124(2.879)$ & $0.388(6.913)$ & $0.149(4.560)$ \\
\hline INT & $0.225(4.133)$ & $0.218(2.336)$ & $0.106(2.214)$ \\
\hline Adj. R $^{2}$ & $3.744(3.913)$ & $11.385(5.168)$ & $7.230(3.599)$ \\
\hline D-W & 0.905 & 0.770 & 0.894 \\
\hline Schwarz criterion & 0.920 & 0.367 & 0.823 \\
\hline AIC & -0.043 & 0.754 & -0.011 \\
\hline Methodology & -0.352 & 0.414 & -0.320 \\
\hline
\end{tabular}

Note: TBR is the T-bill rate. TDR is the time-deposit rate. CFR is the cost of funds rate. INT is the intercept term. Figures in the parenthesis are t-ratios.

\section{References}

1. Al-Saji, Amer K., "The Effect of Government Budget Deficits on Real Interest Rates: Empirical Evidence from Italy, 1960:1-1990:2," International Review of Economics and Business, Vol. 38, No. 10-11, pp. 871878, 1991.

2. $\quad$ Barth, James R., George R. Iden, and Frank S. Russek, "Do Federal Deficits Really matter?" Contemporary Policy Issues, Vol. 3, No. 1, pp. 79-95, 1984-85.

3. Barth, James, R. George Iden, and Frank S. Russek, "Federal Borrowing and Short Term Interest Rates: Comment," Southern Economic Journal, Vol. 52, No. 2, pp. 554-559, 1985.

4. Barro, Robert J., "Economic Growth in a Cross Section of Countries," Quarterly Journal of Economics, Vol. 106, No. 2, pp. 407-443, 1991.

5. Bremnes, Helge, Oystein Gjerde,and Frode Soettem, "Linkages among Interest Rates in the United States, Germany and Norway," Scandinavian Journal of Economics, Vol. 103, No. 1, pp. 127-145, 2001.

6. Coppock, Lee and Marc Poitras, "Evaluating the Fisher Effect in Long-Term Cross-Country Averages," International Review of Economics and Finance, Vol. 9, No. 2, pp. 181-192, 2000.

7. Gali, Jordi, "How Well Does the IS-LM Model Fit Postwar U.S. Data?" Quarterly Journal of Economics, Vol. 107, No. 2, pp. 709-738, 1992.

8. Hoelscher, Gregory, "Federal Borrowing and Short Term Interest Rates," Southern Economic Journal, Vol. 50, No. 1, pp. 319-333, 1983.

9. Hsing, Yu, "The Determinants of Interest Rates in Taiwan: An Application of the Augmented ISLM Model," Journal of Economics, Vol. 24, No. 1, pp. 107-114, 1998.

10. Iscan, Talan, "Devaluations and Aggregate Output Fluctuations: A Random Coefficient Regression Model for Mexico," Applied Economics, Vol. 29, No. 12, pp. 1575-1584, 1997.

11. Junttila, Juha, "Testing an Augmented Fisher Hypothesis for a Small Open Economy: The Case of Finland," Journal of Macroeconomics, Vol. 23, No. 4, pp. 577-599, 2001.

12. Kamin, Steve B. and Rogers, John H., "Output and the Real Exchange Rate in Developing Countries: An Application to Mexico," Journal of Development Economics, Vol. 61, No. 1, pp. 85-109, 2000.

13. Laopodis, Nikiforos T., "International Interest-Rate Transmission and the 'German Dominance Hypothesis' within EMS," Open Economies Review, Vol. 12, No. 4, pp. 347-377, 2001.

14. McCallum, Bennett T. and Edward Nelson, "An Optimizing IS-LM Specification for Monetary Policy and Business Cycle Analysis," Journal of Money, Credit, and Banking, Vol. 31, No. 3, pp. 296-316, 1999.

15. MacDonald, Ronald and Jun Nagayasu, "The Long-Run Relationship between Real Exchange Rates and Real Interest Rate Differentials: A Panel Study,” IMF Staff Papers, Vol. 47, No. 1, pp. 116-128, 2000. 
Notes 